\title{
Mehanička trombektomija - nova metoda liječenja akutnog ishemijskog moždanog udara
}

\section{Mechanical thrombectomy - new treatment method in acute ischemic stroke}

\author{
Boris Bezak $^{1 *}$, Slavica Kovačić1,2, Vladimira Vuletić ${ }^{1,2}$, Damir Miletić ${ }^{1,2}$, Lovro Tkalčić ${ }^{1}$, \\ Siniša Knežević ${ }^{2}$ David Bonifačićc ${ }^{2}$ Marina Bralić
}

${ }^{1}$ Klinički bolnički centar Rijeka, Rijeka, Hrvatska

${ }^{2}$ Sveučilište u Rijeci, Medicinski fakultet, Rijeka, Hrvatska

Sažetak. U zadnjem desetljeću paradigma liječenja akutnog ishemijskog moždanog udara značajno je promijenjena. Za razliku od nekadašnjeg pasivnog pristupa koji je podrazumijevao medikamentoznu terapiju i medicinsko praćenje, danas se primjenjuje aktivno liječenje koje uključuje intravensku trombolizu i mehaničku trombektomiju. Mehanička trombektomija počela se provoditi početkom ovog stoljeća, no značajan procvat metode započeo je objavom nekoliko multicentričnih randomiziranih studija (MR CLEAN, ESCAPE, SWIFT PRIME, REVASCAT, THRACE, PISTE) koje su 2015. godine potvrdile dobrobit ove metode liječenja. Danas je dokazano da je mehanička trombektomija povoljna i poželjna metoda liječenja bolesnika $s$ akutnim ishemijskim moždanim udarom. Razvoj novih dijagnostičkih uređaja i standardizacija protokola snimanja omogućila je objektivniju procjenu stupnja oštećenja parenhima mozga, što je izravno utjecalo na odluku o daljnjem liječenju. Danas je postupak mehaničke trombektomije moguće provesti unutar 24 sata od nastupa simptoma, što su potvrdile i multicentrične randomizirane studije, DAWN i DEFUSE 3. Svakodnevni napredak mehaničke trombektomije doveo je do liječenja i distalnijih okluzija, poput M2 i M3 segmenta srednje moždane arterije i proksimalnih okluzija anteriorne i posteriorne moždane cirkulacije. Istovremeno je neurointervencijski tim postao veoma važna karika u lancu liječenja bolesnika s moždanim udarom. Nedavnom implementacijom mehaničke trombektomije u standardan protokol liječenja bolesnika $s$ akutnim ishemijskim moždanim udarom u sve kliničke bolničke centre $u$ Republici Hrvatskoj, bolesnicima koji borave u Republici Hrvatskoj omogućeno je liječenje najsuvremenijom metodom, sukladno najnovijim smjernicama.

Ključne riječi: endovaskularno liječenje; mehanička trombektomija; moždani udar; smjernice

Abstract. The paradigm of acute ischemic stroke treatment has changed significantly in the last decade. Clinicians switched from the former passive approach to active treatment that includes intravenous thrombolysis and mechanical thrombectomy. Epiphany of mechanical thrombectomy as a preferable treatment method for acute ischemic stroke started with publication of several multicentred randomized studies (MR CLEAN, ESCAPE, SWIFT PRIME, REVASCAT, THRACE, PISTE), which confirmed the benefits of this method in the year 2015. Today, mechanical thrombectomy is proven to be a favorable and desirable method of treatment for patients with acute ischemic stroke. Further development of new diagnostic devices and standardization of imaging protocols enabled objective estimation of brain damage, which resulted with extension of the time frame in which invasive treatment has potential benefit. Consequently, it is now advised to perform mechanical thrombectomy even 24 hours from symptom onset, which was confirmed by DAWN and DEFUSE 3 studies. The development of new endovascular materials, techniques and trained medical staff resulted with treating more distally located vascular structures, such as occlusions of

*Dopisni autor:

Boris Bezak, dr. med.

Klinički bolnički centar Rijeka

Krešimirova 42, 51000 Rijeka, Hrvatska

E-mail: borisbezak@gmail.com
M2 and M3 segments of the middle cerebral artery and proximal occlusions of anterior and posterior cerebral circulation. Meanwhile, neurointerventional team becamethe crucial link in acute ischemic stroke treatment. With recent implementation of mechanical thrombectomy in every Clinical Hospital Center in Croatia, a modern and up to date treatment of acute ischemic stroke became available to every patient in our country.

Key words: endovascular procedures; guidelines; stroke; thrombectomy 


\section{UVOD}

Moždani udar definiran je kao akutni neurološki deficit uzrokovan cerebrovaskularnim događajem. Može se podijeliti na ishemijski moždani udar i hemoragijski moždani udar. Ishemijski moždani udar znatno je češći, a uzrokovan je okluzijom moždane arterije ${ }^{1}$.

Akutni ishemijski moždani udar (AIMU), nakon akutnog infarkta miokarda, drugi je najčešći uzrok smrti u Europi i odgovoran je za smrt više od milijun Europljana godišnje ${ }^{2}$. Istovremeno, AIMU je vodeći uzrok trajnog invaliditeta u svije$t^{2}$. Glavni uzrok AIMU-a jest okluzija moždanih arterija uslijed tromboze ili tromboembolije, što rezultira prekidom cirkulacije u zahvaćenoj regiji mozga. Prekid cirkulacije dovodi do hipoperfuzije moždanih stanica i u konačnici rezultira njihovom smrću. Klinički se kod bolesnika očituje razvojem parcijalnog ili globalnog neurološkog deficita ${ }^{3}$. Budući da je životni vijek sve duži, a prevalencija osoba treće životne dobi u svijetu je u porastu, procjenjuje se da će broj oboljelih od AIMU-a u godinama koje slijede značajno porasti ${ }^{4}$. Za razliku od ranijeg pasivnog pristupa liječenju koji je podrazumijevao promatranje bolesnika i potpornu terapiju u jedinicama intenzivnog liječenja, posljednjih desetak godina nastupio je revolucionaran preokret u korist aktivnog liječenja AIMU$a^{4}$. Osim liječenja intravenskom trombolizom (IVT) koje je u Europi započelo 2002. g., nova era u liječenju AIMU-a započinje 2015. g., objavom niza multicentričnih randomiziranih studija (MR CLEAN, ESCAPE, SWIFT PRIME, REVASCAT, THRACE, PISTE) koje su potvrdile povoljan učinak endovaskularnog liječenja AIMU-a postupkom mehaničke trombektomije (MT $)^{4,5}$. Nedavno objavljene smjernice Europskog vijeća za mozak (engl. European Brain Council; EBC) procjenjuju da je za aktivno liječenje bolesnika oboljelih od AIMU-a potreban minimalno jedan visoko specijaliziran centar na milijun stanovnika. Prema do sada dostupnim podatcima, trenutno samo jedna trećina bolesnika u Europi koja oboli od AIMU-a, ima omogućen pristup visokospecijaliziranom centru za liječenje moždanog udara, što je daleko ispod željenog cilja². Iz tog razloga ne začuđuje potreba za osposobljavanjem većeg broja zdravstvenih djelatnika koji bi pružali primjerenu skrb

\section{KRATICE I POKRATE}

AIMU akutni ishemijski moždani udar

IVT intravenska tromboliza

MT mehanička trombektomija

CTA kompjutorizirana tomografija - angiografija

nCT nativni pregled kompjutoriziranom tomografijom

OHBP objedinjeni hitni bolnički prijam

CTP kompjutorizirana tomografija - perfuzija

DWI-MRI difuzijska MR sekvencija (engl. diffusion weighted images)

ACM arteria cerebri media

ACA arteria cerebrianterior

PCA arteria cerebri posterior

BA arteria basilaris

VA arteria vertebralis

FLAIR MR sekvencija (engl. fluid attenuated inversion recovery)

$\mathrm{ACl}$ arteria cerebri interna

DEFUSE 3 studija potvrdila je dobrobit endovaskularnog liječenja unutar vremenskog perioda od 16 sati, a DAWN studija unutar 24 sata od nastupa simptoma.

navedenim bolesnicima. U ovom trenutku procijenjeno je, uzimajući u obzir geografske specifičnosti naše regije, da je za populaciju Republike Hrvatske od 4284889 stanovnika6, potrebno osnovati pet visokospecijaliziranih centara koji bi provodili ovaj novi oblik liječenja, kako bi pravovremena zdravstvena skrb bila dostupna svima. U skladu s navedenim, u Republici Hrvatskoj su u posljednje dvije godine dodatno unaprijeđena dva visokospecijalizirana centra za liječenje AlMU-a. U Kliničkom bolničkom centru Rijeka provođenje mehaničkih trombektomija započelo je u lipnju 2019. g, a u Kliničkom bolničkom centru Osijek u studenom 2020. g. Od ranije su u funkciji dva visokospecijalizirana centra u Zagrebu i jedan u Splitu. Unaprjeđenjem posljednja dva centra u Rijeci i Osijeku uspostavljena je cjelovita mreža visokospecijaliziranih centara za liječenje AIMU-a u Republici Hrvatskoj, sukladno trenutnim preporukama i smjernicama relevantnih stručnih društava.

Budući da je vrijeme ključan faktor za uspješno liječenje AIMU-a, važno je provoditi dijagnostičke pretrage prema najnovijim međunarodnim smjernicama i protokolima koji su jasni i praktični, a medicinsko osoblje koje izvodi pretrage 
mora biti primjereno educirano. Osim navedenog, za bolji ishod liječenja važna je dostupnost suvremenih radioloških uređaja i standardizacija protokola snimanja.

Cilj je ovog rada predstaviti najnovija saznanja i smjernice te mišljenja relevantnih stručnih društava na temu dijagnostike i liječenja bolesnika oboljelih od AIMU-a. Naglasak u radu je na invazivnom neuroradiološkom liječenju, odnosno mehaničkoj trombektomiji, kao novoj metodi liječenja AIMU-a.

\section{NEUROLOŠKA PROCJENA I SMJERNICE ZA}

\section{LIJEČENJE BOLESNIKA S AIMU-OM}

Prvi čimbenik uspješnog liječenja je pravovremeno prepoznavanje simptoma i znakova AIMU-a ${ }^{7}$. Iz tog se razloga u Republici Hrvatskoj provode brojne javne tribine i edukacije kojima je cilj upoznati javnost i medicinsko osoblje koje nije usko specijalizirano na polju neurologije da što ranije prepozna simptome i znakove AIMU-a. Danas postoji mnoštvo bodovnih ljestvica za brzu procjenu i zbrinjavanje AIMU-a koje je prihvatilo Američko društvo za neurologiju, poput C-STAT (engl. Cincinnati stroke triage assessment tool), LAMS (engl. Los angeles motor scale), RACE (engl. Rapid arterial occlusion evaluation scale), FAST-ED (engl. Field assessment stroke triage for emergency destination), NIHSS (engl. National institute of health stroke scale), od kojih je potonja najčešće korištena u Republici Hrvatskoj (tablica $1)^{7}$. NIHSS ljestvica je od 1995. g. postala zlatni standard za procjenu i rano prepoznavanje neurološkog deficita kod pacijenata s AIMU-om, a danas se koristi i u svrhu procjene uspješnosti liječenja bolesnika oboljelih od AIMU-a (I,B-NR) ${ }^{8}$. Od 1995. g. do danas NIHSS ljestvica je više puta nadopunjavana kako bi postala sveobuhvatna, točna, ali i jednostavna za korištenje, s konačnim ciljem da je koriste svi liječnici i medicinsko osoblje bez obzira na specijalističko područje ${ }^{7}$. Kada se posumnja na akutni ishemijski moždani udar, procjena neurološkog deficita sukladno NIHSS bodovnoj ljestvici nužna je kako bi se odabrao pravilan protokol i način liječenja te procijenila učinkovitost provedenog liječenja.

Sukladno trenutnim smjernicama, bolesnici s neurološkim deficitom > 6 prema NIHSS bodovnoj ljestvici pogodni su za endovaskularno liječenje $(\mathrm{I}, \mathrm{A})^{8}$. U slučaju bolesnika kojima je radiološkom obradom utvrđena okluzija velike krvne žile i koji se prezentiraju blagim neurološkim deficitom, odnosno NIHSS bodom $\leq 6$, znanstvene studije $\mathrm{i}$ trenutne smjernice ukazuju da će se neurološki deficit ubrzo povećati kada se kolateralne rezerve iscrpe ukoliko se ne pristupi aktivnom liječenju ${ }^{8,9}$. Iz tog se razloga u studiji koju su objavili Haussen i sur., kao i u trenutnim smjernicama, navodi da je kod bolesnika s utvrđenom okluzijom krvne žile na CT angiografiji (CTA) i blažim neurološkim deficitom (NIHSS $\leq 6$ ), razumno provesti liječenje mehaničkom trombektomijom i intravenskom trombolizom, uz određena vremenska ograničenja za svaku metodu ${ }^{8,9}$.

Osim neurološke procjene temeljem NIHSS bodovne ljestvice, važna je i procjena premorbidnog kliničkog statusa, odnosno procjena stupnja invalidnosti prije nastupa AIMU-a, kako bi se mogli odrediti očekivani ishodi nakon provedenog liječenja. Za procjenu premorbidnog kliničkog statusa koristi se modificirana Rankin-ljestvica (engl. modified Rankin scale; mRs) (tablica 2) 8-10. $^{\text {. }}$ Sukladno smjernicama američkog udruženja za srce (engl. American Heart Association; AHA), bolesnici oboljeli od AIMU-a pogodni za endvaskularno liječenje jesu oni s premorbidnim kliničkim statusom 0 i 1 (mRs 0 i 1 ) $(I, A)^{8}$. Smjernice navode da je razumno pristupiti endovaskularnom liječenju i kod bolesnika koji su imali određeni stupanj invalidnosti (mRs $>1$ ) prije nastupa AIMU-a ${ }^{8}$. Znanstveno je potvrđeno da će se najveći broj bolesnika s premorbidnim mRs statusom $>1$ koji su liječeni MT-om, klinički oporaviti do razine invalidnosti koja je postojala i ranije ${ }^{8}$. Unatoč dobrim rezultatima liječenja, smrtnost kod tih bolesnika značajno je veća zbog brojnih podliježućih bolesti, stoga se aktivnom liječenju tih bolesnika mora pristupiti s oprezom (IIb,B-R) ${ }^{8}$.

\section{NEURORADIOLOŠKA PROCJENA I SMJERNICE ZA LIJEČENJE BOLESNIKA S AIMU-OM}

Osim važnosti ranog prepoznavanja simptoma $\mathrm{i}$ znakova AIMU-a, slikovna je dijagnostika jednako važan i ključan čimbenik za odabir bolesnika pogodnih za endovaskularno liječenje, odnosno MT $(I, A)^{8}$. 
Tablica 1. NIHSS bodovna ljestvica7

\begin{tabular}{|c|c|c|c|}
\hline Odgovor & Bodovi & Odgovor & Bodovi \\
\hline \multicolumn{2}{|l|}{ Stupanj stanja svijesti } & \multicolumn{2}{|l|}{ Motorika ruke (lijeva i desna) } \\
\hline Budan & 0 & Bez poremećaja & 0 \\
\hline Mamuran & 1 & Zanošenje ruke kraće od 10 sekundi & 1 \\
\hline Stuporozan & 2 & Pad ruke kraći od 10 sekundi & 2 \\
\hline \multirow{2}{*}{ Komatozan } & \multirow{2}{*}{3} & Nemogućnost pomicanja ruke protiv gravitacije & 3 \\
\hline & & Nemogućnost pomicanja ruku & 4 \\
\hline \multicolumn{2}{|c|}{ Odgovor na pitanja s obzirom na stanje svijesti } & \multicolumn{2}{|l|}{ Motorika nogu (lijeva i desna) } \\
\hline Odgovor na oba pitanja točno & 0 & Bez poremećaja & 0 \\
\hline Odgovara točno na jedno pitanje & 1 & Zanošenje noge kraće od 10 sekundi & 1 \\
\hline \multirow{3}{*}{ Ne odgovara točno ni na jedno pitanje } & \multirow{3}{*}{2} & Pad noge kraći od 10 sekundi & 2 \\
\hline & & Nemogućnost pomicanja noge protiv gravitacije & 3 \\
\hline & & Nemogućnost pomicanja noge & 4 \\
\hline \multicolumn{2}{|c|}{ Odgovor na naredbe s obzirom na stanje svijesti } & \multicolumn{2}{|l|}{ Ataksija } \\
\hline Izvršava obje naredbe točno & 0 & Odsutna & 0 \\
\hline Izvršava jednu naredbu točno & 1 & Jednog ekstremiteta & 1 \\
\hline Ne izvršava ni jednu naredbu točno & 2 & Oba ekstremiteta & 2 \\
\hline \multicolumn{2}{|l|}{ Pupilarni odgovor } & \multicolumn{2}{|l|}{ Osjet } \\
\hline Na oba oka reaktivan & 0 & Normalan & 0 \\
\hline $\mathrm{Na}$ jednom oku reaktivan & 1 & Blago poremećen & 1 \\
\hline Ni na jednom oku reaktivan & 2 & Teško poremećen & 2 \\
\hline \multicolumn{2}{|l|}{ Pogled } & \multicolumn{2}{|l|}{ Jezik/govor } \\
\hline Normalan & & Normalan & \\
\hline Djelomična paraliza pogleda & & Blaga afazija & \\
\hline Totalna paraliza pokreta & & Teška afazija & \\
\hline \multicolumn{2}{|l|}{ Vidno polje } & \multicolumn{2}{|l|}{ Paraliza lica } \\
\hline Nema gubitaka vidnog polja & 0 & Bez paralize & 0 \\
\hline Parcijalna hemianopsija & 1 & Blaga paraliza & 1 \\
\hline Kompletna hemianopsija & 2 & Parcijalna paraliza & 2 \\
\hline Bilateralna hemianopsija & 3 & Potpuna paraliza & 3 \\
\hline \multicolumn{2}{|l|}{ Dizartrija } & \multicolumn{2}{|l|}{ Ugašenost/neosjetljivost dijela tijela } \\
\hline Uredan govor & 0 & Bez ugašenosti/neosjetljivosti & 0 \\
\hline Blaga dizartrija & 1 & Blaga ugašenost/neosjetljivost & 1 \\
\hline Teška dizartrija & 2 & Teška ugašenost/neosjetljivost & 2 \\
\hline
\end{tabular}

Tablica 2. mRs bodovna ljestvica za procjenu premorbidne invalidnosti bolesnika

\begin{tabular}{|c|l|}
\hline Bod & \multicolumn{1}{|c|}{ Status bolesnika } \\
\hline $\mathbf{0}$ & Bez simptoma \\
\hline $\mathbf{1}$ & Bez značajnog invaliditeta. Sposoban izvoditi uobičajene dnevne aktivnosti unatoč blagim simptomima. \\
\hline $\mathbf{2}$ & $\begin{array}{l}\text { Blaga invalidnost. Sposoban obavljati osnovne dnevne zadatke i potrebe bez tuđe pomoći, ali nije sposoban izvršavati } \\
\text { svakodnevne aktivnosti kao ranije. }\end{array}$ \\
\hline $\mathbf{3}$ & Umjerena invalidnost. Potrebna pomoć za izvršavanje pojedinih aktivnosti, ali je u mogućnosti hodati bez tuđe pomoći. \\
\hline $\mathbf{4}$ & $\begin{array}{l}\text { Umjereno teška invalidnost. Nemogućnost obavljanja osnovnih dnevnih potreba bez tuđe pomoći. Nemogućnost } \\
\text { samostalnog hoda. }\end{array}$ \\
\hline $\mathbf{5}$ & Teška invalidnost. Potrebna mu je pomoć i svakodnevna njega. Ne ustaje samostalno iz kreveta. Inkontinencija. \\
\hline $\mathbf{6}$ & Smrt \\
\hline
\end{tabular}


Prema trenutnim smjernicama, prilikom dolaska bolesnika sa sumnjom na akutni ishemijski moždani udar u specijalizirani centar, protokol dijagnostičkih radioloških pretraga mora obuhvaćati sljedeće: nativni pregled mozga kompjutorizira-

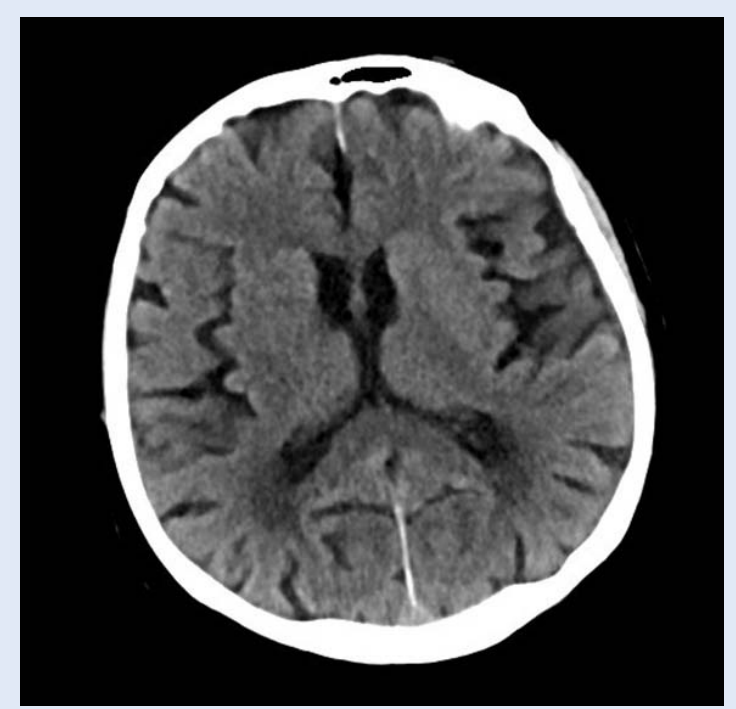

Slika 1. Nativni CT pregled mozga (nCT) (Izvor: arhiva ISSA, KBC Rijeka)

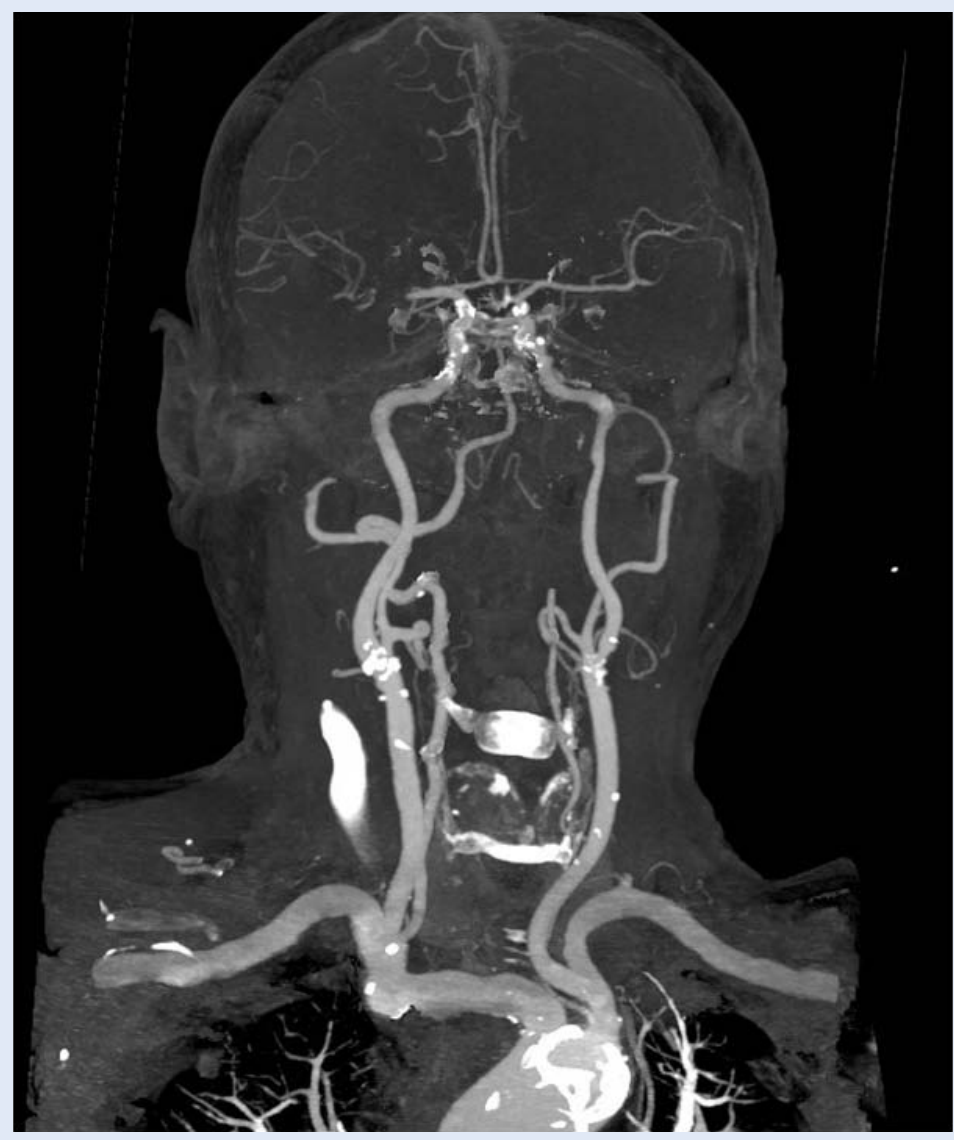

Slika 2. CTA karotidnih i intrakranijskih arterija (Izvor: arhiva ISSA, KBC Rijeka) nom tomografijom (nCT) i CTA karotidnih i intrakranijskih krvnih žila u što kraćem vremenskom roku, poželjno unutar 20 minuta od nastupa simptoma, odnosno neposredno nakon dolaska bolesnika u objedinjeni hitni bolnički prijam (OHBP) (I,B-NR) (slika 1 i slika 2) $)^{8}$. Ukoliko je proteklo više od šest sati od nastupa simptoma, obavezno je pregled nadopuniti CT perfuzijom (CTP) ili difuzijskim MR snimkama (DWI-MRI) kako bi se mogao procijeniti opseg moždanog tkiva koje je potencijalno moguće spasiti, odnosno kako bi se moglo procijeniti je li bolesnik pogodan za endovaskularno liječenje mehaničkom trombektomijom (I,A) (slika 3) (tablica 3) $)^{4,8}$.

Prvi je korak radiološke dijagnostike nCT pregled koji ima za cilj isključiti intrakranijsko krvarenje te potencijalna stanja koja mogu imitirati akutni ishemijski moždani udar, što su ujedno isključni faktori za aktivno liječenje intravenskom trombolizom i mehaničkom trombektomijom. Također, na nCT pregledu važno je utvrditi opseg demarkiranog infarkta ukoliko postoji, što je jedan od isključnih faktora za provođenje MT-a. Ukoliko je opseg demarkiranog infarkta, koji se na nCT pregledu procjenjuje prema ASPECTS bodovnoj ljestvici (engl. Alberta stroke program early CT score), jednak ili manji od 5, tada nije znanstveno potvrđena dobrobit od aktivnog liječenja mehaničkom trombektomijom jer demarkirano područje prvenstveno odgovara jezgri infarkta, odnosno području mozga koje se neće oporaviti unatoč rekanalizaciji krvne žile i uspostavi reper-

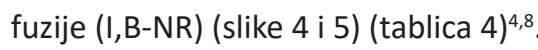

Kada eliminiramo isključne faktore na nCT pregledu, a i dalje postoji klinički opravdana sumnja na AIMU, sljedeći dijagnostički korak u protokolu jest CTA karotidnih i intrakranijskih arterija čiji je cilj procjena mjesta okluzije krvne žile ${ }^{4}$. U novije vrijeme na važnosti je dobila i procjena kolateralnog optoka u mozgu, što se također procjenjuje pomoću CTA i bitan je čimbenik koji govori u prilog očekivane brzine razvoja infarkta kod bolesnika (tzv. spori i brzi progresori) ${ }^{4}$. Ukoliko se na CTA utvrdi okluzija krvne žile koja je uzrok infarkta, potrebno je procijeniti je li bolesnik pogodan za endovaskularno liječenje. Ukoliko je endovaskularno liječenje moguće, potrebno je u što kraćem roku transportirati bolesnika u angiosalu, idealno 
Tablica 3. Dijagnostički slikovni protokol kod bolesnika koji se prezentiraju simptomima AIMU-a ${ }^{4}$

\begin{tabular}{|l|l|l|}
\hline Slikovne metode & Tehnički parametri & Pitanja/Rezultati \\
\hline NATIVNI CT $(\mathrm{nCT})$ & Procjena moždanog parenhima & $\begin{array}{l}\text { Krvarenje? Alternativne dg.? } \\
\text { Procjena ASPECTS }\end{array}$ \\
\hline CT angiografija (CTA) & Snimanje od luka aorte do verteksa lubanje & $\begin{array}{l}\text { Okluzija velike krvne žile? } \\
\text { Tandem lezija? }\end{array}$ \\
\hline Cerebralna perfuzija & Obuhvatiti teritorij od interesa & $\begin{array}{l}\text { Volumen infarkta? } \\
\text { Procjena penumbre }\end{array}$ \\
\hline MR & DWI/FLAIR & Omjer penumbre/infarkta \\
\hline
\end{tabular}

unutar 30 minuta od nastupa simptoma8. Postkontrastni prikaz na CTA, osim prikaza mjesta okluzije i kolateralnog optoka, daje uvid u anatomiju luka aorte i karotidnih arterija što operateru služi kao vodilja prilikom planiranja endovaskularnog zahvata ${ }^{4}$.

S obzirom na lokalizaciju okluzije, dobrobit liječenja mehaničkom trombektomijom dokazana je kod bolesnika s okluzijom u početnom (M1) odsječku srednje moždane arterije $(A C M)(I, A)^{8}$. Zbog napretka u izradi materijala koji se koriste tijekom zahvata, danas je moguće provesti endovaskularno liječenje i na udaljenijim vaskularnim strukturama [M2 i M3 odsječak srednje moždane arterije (ACM), A1 i A2 odsječak prednje moždane arterije ( $A C A), P 1$ odsječak stražnje moždane arterije (PCA) te bazilarne (BA) i vertebralnih arterija (VA)], iako je razina dokaza još uvijek niska za zahvate te vrste [IIb, B-R razina dokaza za okluzije na udaljenim segmentima arterija prednje

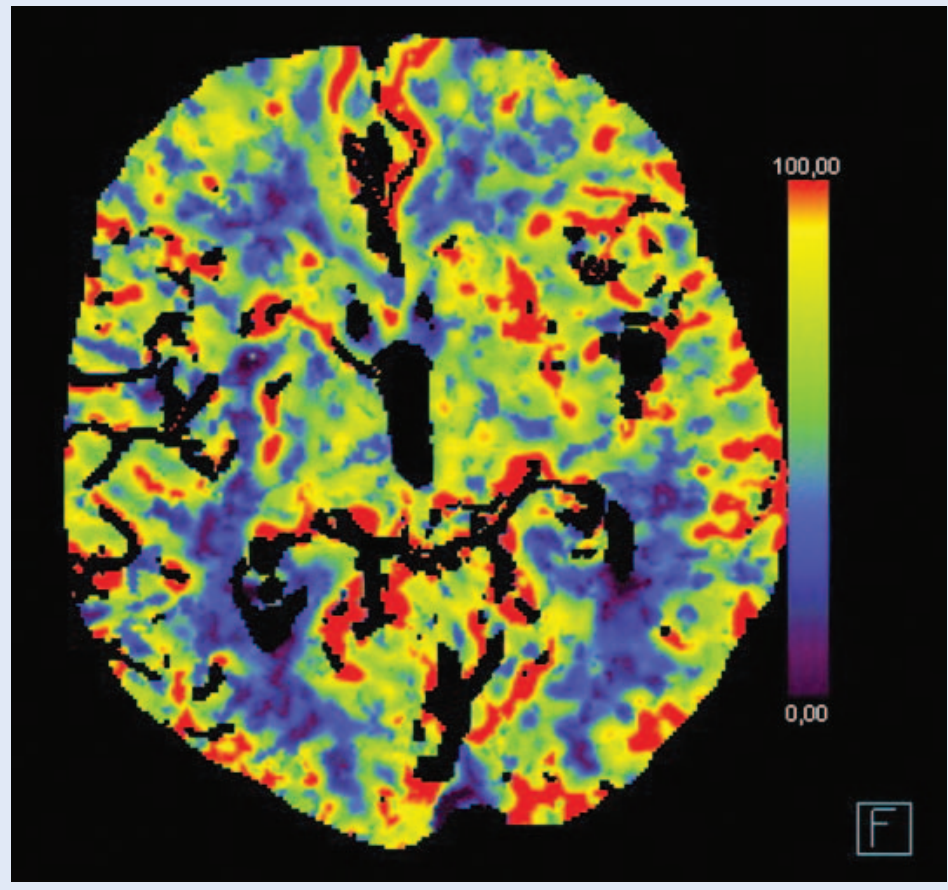

Slika 3. CTP mozga (Izvor: arhiva ISSA, KBC Rijeka)

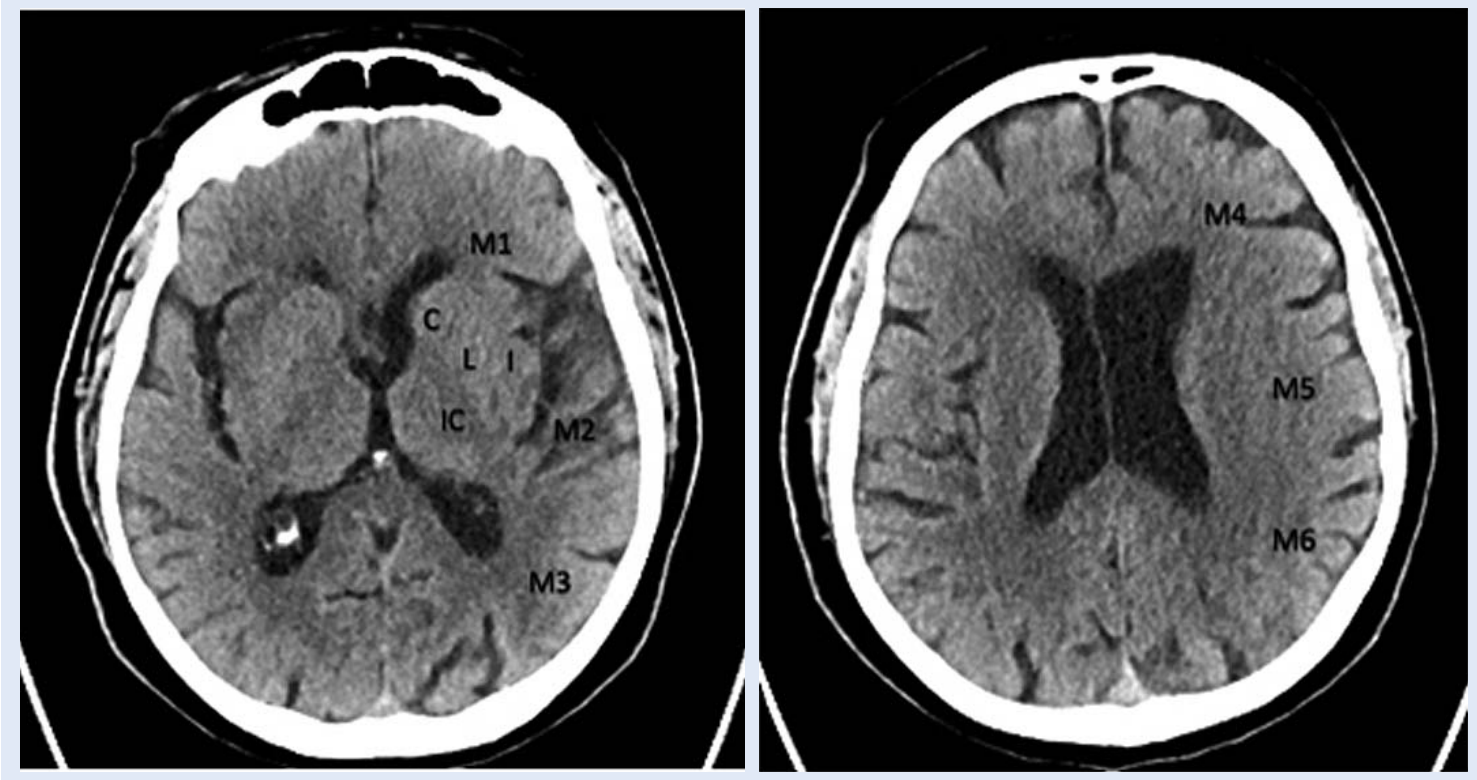

Slike 4. i 5. ASPECTS regije mozga (Izvor: arhiva ISSA, KBC Rijeka) 
Tablica 4. ASPECTS ljestvica za procjenu ranih ishemijskih promjena na nCT

\begin{tabular}{|l|c|}
\hline \multicolumn{1}{|c|}{ Zahvaćena regija } & Bod \\
\hline Bazalni gangliji & -1 \\
\hline C - Kaudatna jezgra & -1 \\
\hline L - Lentiformna jezgra & -1 \\
\hline I - Inzula & -1 \\
\hline IC - Kapsula interna & \\
\hline Subganglijska područja & -1 \\
\hline M1 - Frontalni operkulum & -1 \\
\hline M2 - Anteriorni segment temporalnog režnja & -1 \\
\hline M3 - Posteriorni temporalni režanj & \\
\hline Supraganglijska područja & -1 \\
\hline M4 - Srednji frontalni girus & -1 \\
\hline M5 - Superiorni frontalni girus & -1 \\
\hline M6 - Supramarginalni i angularni girus
\end{tabular}

* Svako od 10 navedenih područja gdje je prisutan gubitak diferencijacije sive/bijele tvari umanjuje ukupni zbroj bodova za 1 bod

moždane cirkulacije te IIb, C-LD razina dokaza za okluzije na proksimalnim segmentima stražnje moždane cirkulacije $]^{8}$. Iz navedenog možemo zaključiti da, iako postoje studije provedene na manjim uzorcima bolesnika i nerandomizirane metaanalize koje potvrđuju dobrobit endovaskularnog liječenja na udaljenijim vaskularnim strukturama mozga, za definitivnu potvrdu učinkovitosti metode moramo sačekati multicentrične randomizirane studije . $^{8}$.

BASICS (engl. Basilar artery international cooperation registry study) je trenutno jedina dostupna multicentrična randomizirana studija koja je analizirala bolesnike s okluzijom na razini bazilarne arterije na većem uzorku od 592 bolesnika. Studija navodi relativno loš klinički ishod (mRs 4 i više) u $68 \%$ bolesnika s okluzijom bazilarne arterije, bez obzira na izbor metode liječenja (IVT ili MT), ali naglašava da je moguće provesti MT i kod te skupine bolesnika ${ }^{11}$.

Ukoliko nema kontraindikacija, preporučuje se primijeniti IVT kod svih bolesnika sa simptomatskim AIMU-om koji su pristigli u specijalizirani centar unutar vremenskog prozora od 4,5 sati, odmah nakon utvrđivanja okluzije na CTA, neovisno o tome hoće li se provesti endovaskularni zahvat, bez odgode i potrebe za praćenjem rezolucije simptoma nakon primijenjenog IVT-a $(\mathrm{I}, \mathrm{A})($ slika 6) .

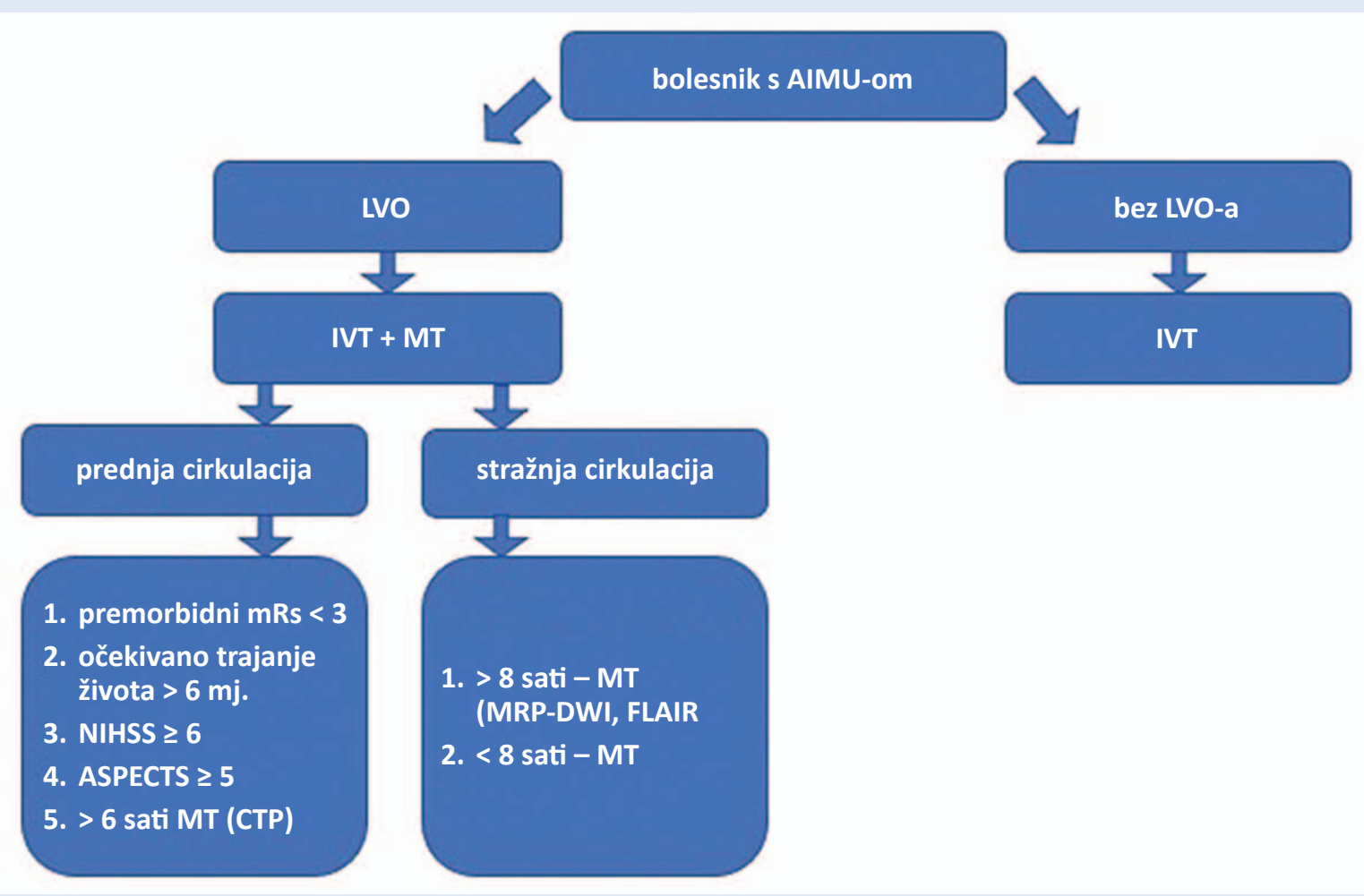

Slika 6. Shematski prikaz smjernica za provedbu mehaničke trombektomije kod bolesnika s akutnim ishemijskim moždanim udarom ${ }^{4}$ * LVO (engl. large vessel oclusion), ** MRP - MR perfuzija 
Okluzije na razini mikrocirkulacije, distalno od proksimalnih segmenata intrakranijskih arterija prednje i stražnje cirkulacije, za sada ostaju domena aktivnog neurološkog liječenja primjenom IVT-a, na što ukazuju i nedavno objavljene studije te aktualne smjernice ${ }^{8,12}$.

Spomenute dijagnostičke metode (CTA, CTP i MRDWI) pridonijele su objektivnijoj procjeni ranih ishemijskih promjena na mozgu i na taj su način izravno utjecale na modifikaciju modaliteta liječenja od kojeg se očekuje povoljan klinički ishod. Donedavno se smatralo da je vremenski period od šest sati krajnja granica unutar koje se bolesniku može pružiti endovaskularno liječenje, kao kompromis između potencijalne dobrobiti i relativnog rizika zahvata tog tipa ${ }^{4,13}$. Navedeno govori u prilog tome da kod pacijenata s nepoznatim vremenom nastanka simptoma, odnosno kod pacijenata kojima su simptomi ishemijskog moždanog udara nastupili u nepoznato vrijeme tijekom noći (engl. wake up stroke), nije bilo moguće provesti aktivno liječenje. Zahvaljujući naprednim tehnološkim rješenjima, poput CTA i CTP te difuzijskim snimkama na magnetskoj rezonanciji (DWI-MRI), moguće je procijeniti kolateralnu vaskularnu opskrbu te opseg hipoperfundiranog i vijabilnog moždanog tkiva. Na taj je način bolesnicima s AIMU-om nepoznatog vremena nastanka omogućeno endovaskularno liječenje i izvan vremenskog „prozora” od šest sati ${ }^{4}$. Pri tome CTA služi za procjenu kolateralne vaskularne opskrbe, a CTP za procjenu omjera infarkta i vijabilnog, hipoperfundiranog parenhima mozga, odnosno penumbre.

Ukoliko se pristupa snimanju na magnetskoj rezonanciji, za analizu vremena proteklog od nastupa simptoma koristimo kratak protokol snimanja.
Navedeni protokol traje oko 15 minuta i uključuje dvije sekvencije, DWI i FLAIR ${ }^{4}$. Analiza moždanog parenhima na navedenim sekvencijama može pružiti informaciju o približno točnom vremenu nastanka simptoma i na taj način izravno utjecati na odabir metode liječenja. Hiperintenziteti nastali zbog hipoperfuzije mozga na FLAIR sekvenciji prezentiraju se nakon 4,5-12 sati od nastupa simptoma, dok na DWI sekvencijama postaju vidljivi nakon nekoliko minuta (engl. DWI/FLAIR mismatch $)^{14}$. Budući da je primjena IVT-a kontraindicirana ukoliko simptomi traju duže od 4,5 sata, postojanje hiperintenzivnih zona na FLAIR sekvenciji uputit će nas da nije preporučljivo primijeniti IVT, zbog pojačanog rizika od nastanka intracerebralne hemoragije $\mathrm{e}^{14}$.

Sukladno posljednjim smjernicama, dobrobit endovaskularnog liječenja AIMU-a primjenom MT-a potvrđena je za bolesnike koji dolaze u specijalizirani centar zbog liječenja moždanog udara nakon vremenskog „prozora” od šest sati. To su bolesnici kojima je zahvaljujući održanom kolateralnom protoku, održan velik opseg vijabilnog moždanog tkiva, što su potvrdile i multicentrične, randomizirane studije DAWN i DEFUSE $3^{15,16}$. Navedene studije zaključuju da, iako je poželjno započeti liječenje što ranije, postoji mogućnost da se ono provede i izvan šestosatnog vremenskog prozora, uz očekivan povoljan ishod liječenja. DEFUSE 3 studija potvrdila je dobrobit endovaskularnog liječenja unutar vremenskog perioda od 16 sati, a DAWN studija unutar 24 sata od nastupa simptoma, ukoliko perfuzijske i difuzijske snimke utvrde postojanje dovoljno velike penumbre, a bolesnici zadovoljavaju i ostale uključne i isključne kriterije koji su navedeni u tablici $5(\mathrm{I}, \mathrm{A})^{4,8,15,16}$.

Tablica 5. DAWN i DEFUSE 3 kriteriji za provedbu MT-a nakon 6 sati od nastupa simptoma ${ }^{15-16}$

\begin{tabular}{|l|l|}
\hline \multicolumn{1}{|c|}{ DAWN } & \multicolumn{1}{c|}{ DEFUSE 3} \\
\hline NIHSS $\geq 10,6-24$ sata od nastupa simptoma & NIHSS $\geq 6,6-16$ sati od nastupa simptoma \\
\hline Slikovne metode: & Slikovne metode: \\
ACl i/ili ACM - M1 okluzija & ACl i/ili ACM okluzija \\
Infarkt $<1 / 3$ ACM & Infarkt $<70 \mathrm{ml}$ \\
Klinički deficit/volumen infarkta & Omjer hipoperfuzije/jezgre infarkta $\geq 1,8$ \\
A: $\geq 80 \mathrm{~g}$, NIHSS $\geq 10$, vol. infarkta $<21 \mathrm{ml}$ & \\
B: $<80 \mathrm{~g}$, NIHSS $\geq 10$, vol. infarkta $<31 \mathrm{ml}$ & \\
C: $<80 \mathrm{~g}$, NIHSS $\geq 20$, vol. infarkta $31-51 \mathrm{ml}$ & \\
\hline
\end{tabular}




\section{ANESTEZIOLOŠKA POTPORA I LIJEČENJE}

Anesteziološka potpora i liječenje bolesnika s AlMU-om podrazumijeva sedaciju i/ili opću anesteziju. Istraživanje Brinjikjija i sur. iz 2017. g. u kojem je analizirano 4716 bolesnika liječenih mehaničkom trombektomijom, potvrdilo je povoljan učinak sedacije bolesnika u odnosu na opću anesteziju tijekom MT-a ${ }^{17}$. Navedeno vrijedi za bolesnike kojima je dišni sustav prohodan i koji su u mogućnosti biti mirni tijekom zahvata ${ }^{17}$. Spomenuta studija navodi veći postotak smrtnosti i respiratornih komplikacija te manju vjerojatnost povoljnog ishoda kod bolesnika kojima je zahvat učinjen u općoj anesteziji u odnosu na bolesnike koji su sedirani tijekom zahvata. Glavni razlog lošijih ishoda bolesnika koji su uvedeni u opću anesteziju jest produženo vrijeme od nastupa simptoma do punkcije zbog vremena potrebnog za postavljanje endotrahealnog tubusa te zbog pada srednjeg arterijskog tlaka prilikom uvođenja bolesnika u opću anesteziju ${ }^{17}$. S druge strane, AnStroke studija i studija provedena od Schönenbergera i sur. na uzorku od 150 bolesnika navode da nema statistički značajne razlike između obiju metoda ${ }^{18,19}$. Temeljem navedenog možemo zaključiti da je sedacija bolesnika poželjna anesteziološka metoda potpore tijekom zahvata mehaničke trombektomije, a opću anesteziju treba primijeniti u slučajevima kada je dišni put iz bilo kojeg razloga ugrožen ili kada su bolesnici izrazito nemirni tijekom zahvata.

MEHANIČKA TROMBEKTOMIJA - OPIS ZAHVATA I NAJČEŠĆE KORIŠTENE METODE

Mehanička trombektomija je endovaskularna metoda liječenja AIMU-a čiji je cilj uklanjanje tromba i/ili tromboembolusa u svrhu rekanalizacije okludirane krvne žile, s konačnim ciljem uspostave potpune reperfuzije parenhima mozga. Zahvat započinje punkcijom krvne žile, najčešće zajedničke femoralne arterije, Seldingerovom tehnikom. Metoda se bazira na upotrebi čitavog niza endovaskularnih uređaja i materijala [npr. duge uvodnice, hidrofilne mikrožice, aspiracijski kateteri i balon-kateteri, samošireći uvlačivi stentovi (engl. stent retriever), aspiracijske pumpe itd.]. Navedeni materijali posebno su dizajnirani kako bi omogućili što lakši i brži pristup do okludi- rane krvne žile. U ovom radu predstavljamo četiri najčešće korištene metode tehničke izvedbe mehaničke trombektomije ${ }^{20}$.

Prva je ADAPT tehnika (engl. a direct aspiration first pass tehnique) koja uključuje aspiraciju tromba koristeći samo aspiracijski kateter postavljen kroz dugu uvodnicu promjera 5 do 6 frencha s ciljem aspiracije tromba i/ili tromboembolusa ${ }^{20}$. Aspiracija se može učiniti manualno, koristeći negativni tlak u šprici ili uz pomoć aspiracijske pumpe koja sama kontinuirano proizvodi negativan tlak i vrši aspiraciju tromba. Da bi se izvršila aspiracija tromba, potrebno je aspiracijski kateter postaviti neposredno uz tromb, što se čini uz pomoć fluoroskopske navigacije i invazivnog kontrastnog prikaza vaskularnih struktura. Da bi postavili aspiracijski kateter na željeno mjesto, on mora proći kroz različite vrste uvodnica i/ili navodećih katetera (engl. guiding catheter) koji se postavljaju selektivno u unutarnju karotidnu arteriju ( $\mathrm{ACl}$ ). Za selektivni pristup koriste se i selektivni kateteri te hidrofilne i/ili nitinolske žice (slika 7). Druga najčešće korištena tehnika je SOLUMBRA ${ }^{20}$. Ona uključuje istovremeno korištenje samoširećih uvlačivih stentova i aspiracije pomoću aspiracijskog katetera. Cilj je ove tehnike „uglaviti” tromb u porozni samošireći uvlačivi stent i polagano ga povlačiti u aspiracijski kateter uz istovremenu manualnu aspiraciju ili aspiraciju uz pomoć aspiracijske pumpe (slika 8).

Sljedeća tehnika SOLUMBRA+BGC uključuje privremenu proksimalnu okluziju pomoću balon-ka-

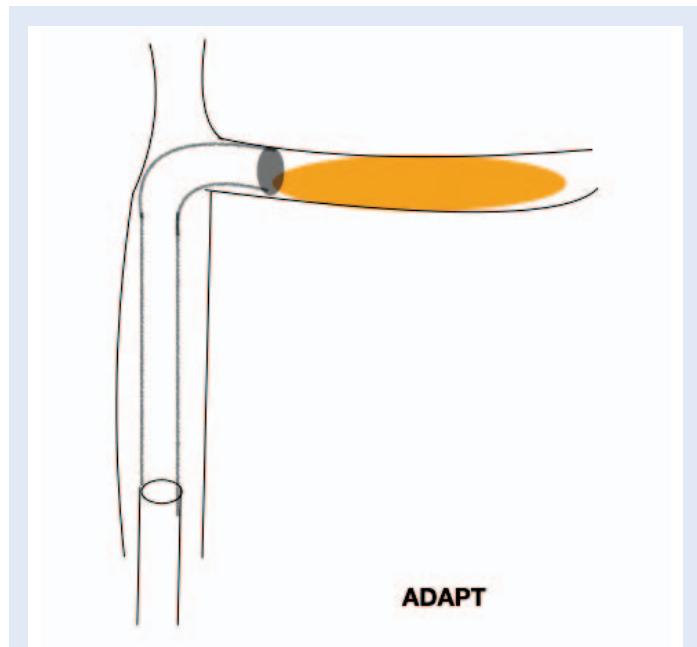

Slika 7. ADAPT tehnika mehaničke trombektomije 


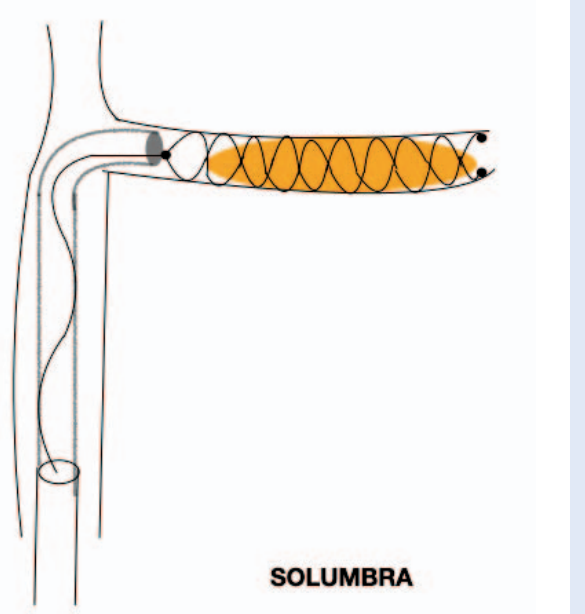

Slika 8. SOLUMBRA tehnika mehaničke trombektomije

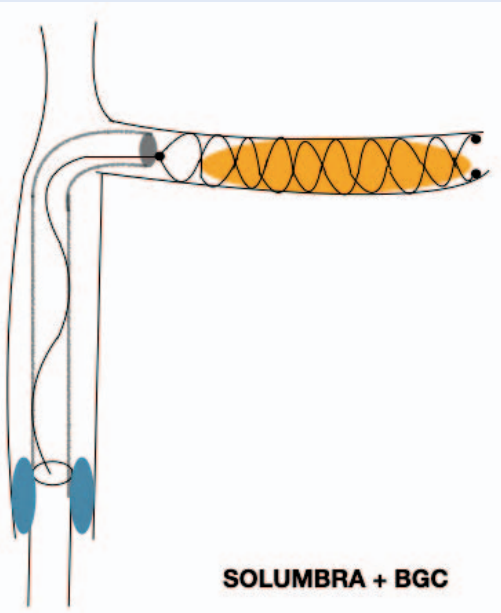

Slika 9. SOLUMBRA+BCG tehnika mehaničke trombektomije

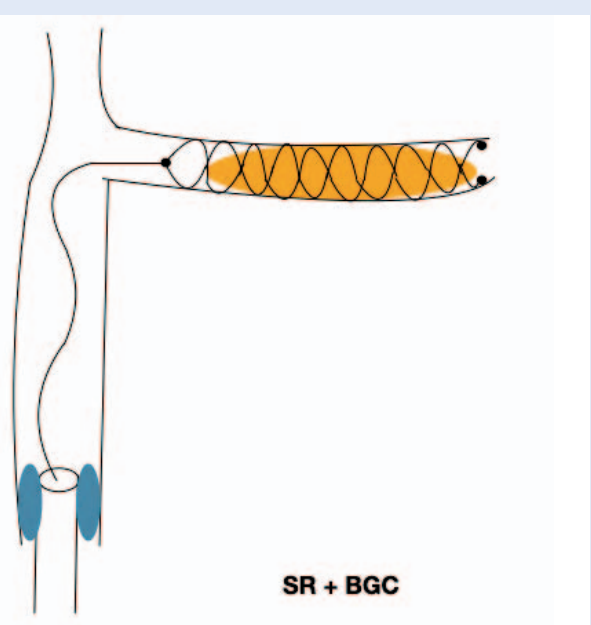

Slika 10. SR + BCG tehnika mehaničke trombektomije tetera s ciljem prekida distalnog protoka krvi, a u svrhu sprječavanja defragmentacije tromba i distalne tromboembolije ${ }^{20}$. Ova se tehnika bazira na selektivnom pozicioniranju balon-katetera u $\mathrm{ACl}$ dok kroz njega prolazi aspiracijski kateter koji se postavlja uz proksimalni odsječak tromba, te samošireći uvlačivi stent koji se otpušta u samom trombu. SOLUMBRA+BGC tehniku najčešće koriste iskusniji operateri jer uključuje više koraka i bolje poznavanje šire palete endovaskularnih materijala, što je čini najzahtjevnijom i ujedno najskupljom (slika 9) ${ }^{20}$.

Posljednja tehnika SR+BGC uključuje korištenje samoširećeg uvlačivog stenta i balon-katetera bez istovremene aspiracije te se rijetko koristi (slika 10) ${ }^{20}$.

Sukladno nedavno objavljenoj studiji koja je obuhvatila 450 bolesnika, zaključeno je da je veći stupanj reperfuzije postignut kada su korištene tehnike SOLUMBRA i SLOUMBRA+BGC (86\%) u odnosu na ADAPT tehniku $(66 \%)^{21}$. Ista studija navodi da je korištenjem kombiniranih tehnika kao što su SOLUMBRA i SOLUMBRA+BGC postignut manji stupanj defragmentacije tromba i distalne tromboembolije $(9,6 \%)$ u odnosu na ADAPT tehniku (11,6\%). Navedeno implicira da izbor tehnike kod postupka MT-a uvelike ovisi o iskustvu i preferencijama operatera, ali u većoj mjeri ide u prilog onima koje koriste samošireći uvlačivi stent, zbog većeg postotka reperfuzije i manjeg postotka defragmentacije tromba i distalne tromboembolije, $u$ odnosu na tehnike koje ne koriste samošireći uvlačivi stent ${ }^{20,21}$. ADAPT tehnika pokazala se jednako učinkovitom kao i tehnike koje uključuju samošireći uvlačivi stent za bolesnike koji zadovoljavaju sljedeće kriterije: mRs bod 0 i 1; okluzija na razini M1 segmenta ACM; bolesnici stariji od 18 godina; NIHSS $\geq 6$; ASPECTS $\geq 6$; vrijeme od nastanka okluzije $\leq 6$ sati $(\mathrm{I}, \mathrm{B}-\mathrm{R})^{8}$.

\section{PROCJENA TEHNIČKE USPJEŠNOSTI I KLINIČKOG ISHODA NAKON MT-A}

Procjena tehničke uspješnosti rekanalizacije vrši se $u$ angiosali neposredno nakon učinjenog endovaskularnog zahvata sukladno eTICI bodovnoj ljestvici (engl. Thrombolysis In Cerebral Infarction). Ljestvicom eTICI procjenjujemo opseg rekanaliza- 


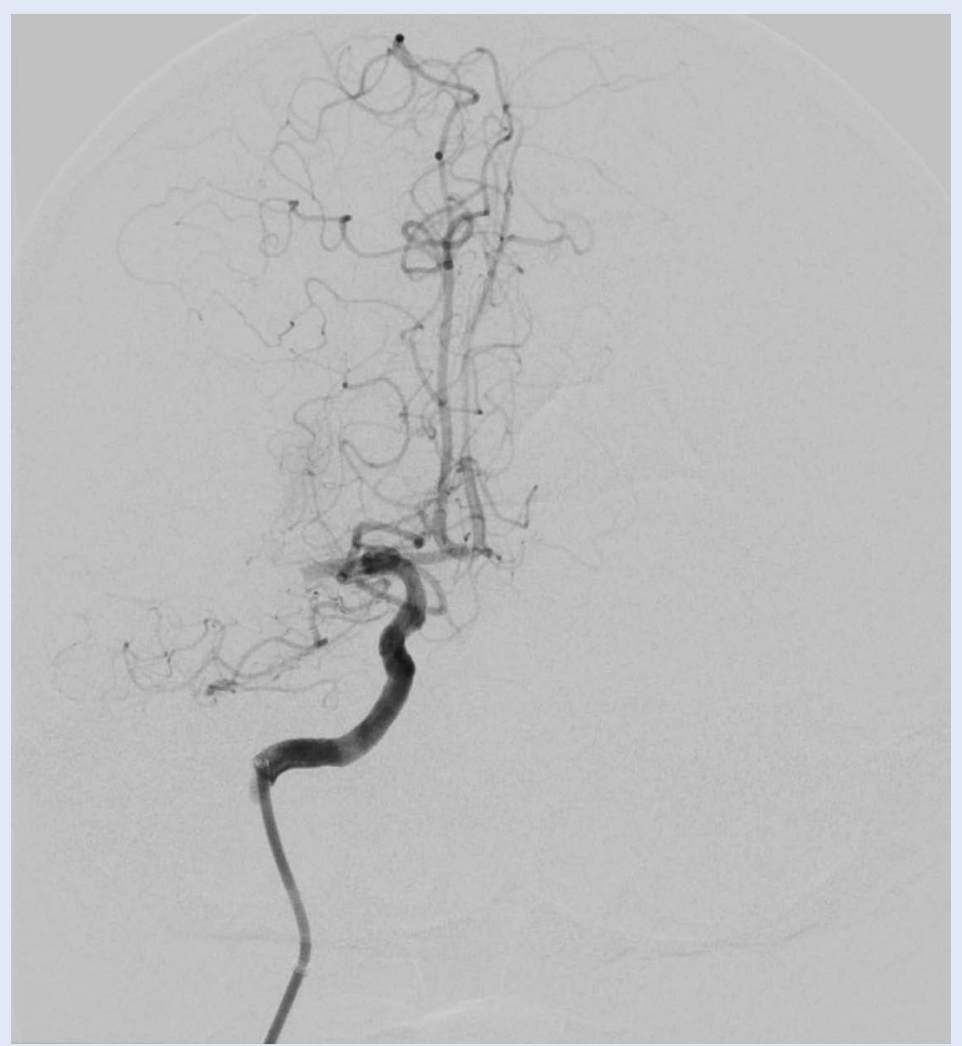

Slika 11. Mehanička trombektomija - inicijalna DSA snimka prije aspiracije tromba (Izvor: KBC Rijeka, arhiva ISSA)

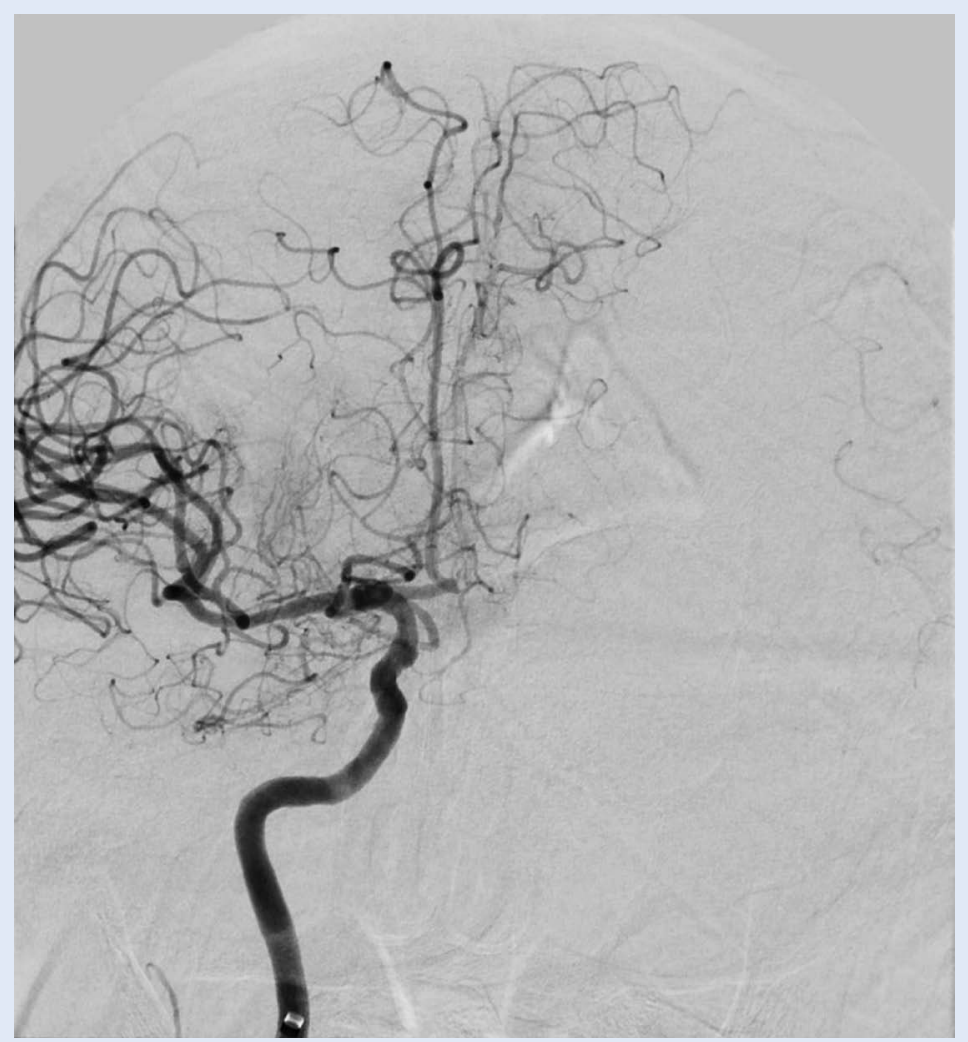

Slika 12. Mehanička trombektomija - DSA snimka nakon aspiracije tromba, $\mathrm{TICl} 3$ protok (Izvor: KBC Rijeka, arhiva ISSA)
Tablica 6. Bodovna ljestvica eTICl za procjenu uspješnosti reperfuzije nakon provedene mehaničke trombektomije ${ }^{22}$

\begin{tabular}{|c|l|}
\hline eTICI & \multicolumn{1}{|c|}{ Opseg reperfuzije } \\
\hline $\mathbf{0}$ & Neuspješna reperfuzija (0 \%) \\
\hline $\mathbf{1}$ & $\begin{array}{l}\text { Redukcija tromba bez reperfuzije distalnih } \\
\text { arterija (0 \%) }\end{array}$ \\
\hline $\mathbf{2 a}$ & Reperfuzija od 1 do $49 \%$ teritorija \\
\hline $\mathbf{2 b 5 0}$ & Reperfuzija od 50 do $66 \%$ teritorija \\
\hline $\mathbf{2 b 6 7}$ & Reperfuzija od 67 do $89 \%$ teritorija \\
\hline $\mathbf{2 c}$ & Reperfuzija od 90 do $99 \%$ teritorija \\
\hline $\mathbf{3}$ & Potpuna reperfuzija (100\%) \\
\hline
\end{tabular}

cije i reperfuzije na suptrakcijskim snimkama (sli-

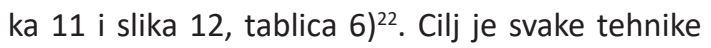
što ranija potpuna ili gotovo potpuna rekanalizacija okludirane arterije i što veći postotak reperfuzije moždanog parenhima, odnosno protok TICI 3 ili 2 b. Značajno bolji klinički ishod uočava se kod potpune reperfuzije nakon obavljenog neurointervencijskog zahvata ( $\mathrm{TICl} 3$ ), u odnosu na parcijalnu rekanalizaciju i reperfuziju $(<\mathrm{TICl} 2 \mathrm{~b})$, što potvrđuje i studija koju su objavili Jovin i sur. ${ }^{23}$. Nadalje, Wu i sur. u svojoj studiji navode da je moguće postići značajne dugoročne financijske uštede ukoliko se kod bolesnika postigne $\mathrm{TICl} 3 \mathrm{ili}$ $2 \mathrm{~b}$ stupanj reperfuzije, $u$ odnosu na parcijalnu reperfuziju (< $\mathrm{TICl} 2 \mathrm{~b})$ gdje je daljnji trošak liječenja i rehabilitacije tih bolesnika znatno veći ${ }^{24}$.

Neurološki pregled s ciljem procjene kliničkog ishoda nakon učinjenog MT-a provodi se temeljem NIHSS bodovne ljestvice u više koraka - neposredno nakon obavljenog zahvata, tijekom boravka bolesnika u bolnici, prije samog otpusta te nakon dovršene rehabilitacije. Na kontrolnim neurološkim pregledima prije otpusta i 90 dana nakon MT-a, a nakon rehabilitacije, obavezno se procjenjuje stupanj invalidnosti bolesnika temeljem mRs bodovne ljestvice koja je pokazatelj uspješnosti provedenog liječenja.

\section{POSTPROCEDURALNA SKRB}

Važno je napomenuti da liječenje akutnog ishemijskog moždanog udara nije završeno nakon učinjenog zahvata mehaničke trombektomije. Od iznimne je važnosti i rana postproceduralna skrb u sljedećih 24- 48 sati koja obuhvaća neurološki i anesteziološki nadzor vitalnih parametara, pri- 
mjerenu oksigenaciju, regulaciju krvnog tlaka, glukoze u krvi i tjelesne temperature uz primjerenu nutritivnu potporu i njegu bolesnika. Rano vertikaliziranje bolesnika unutar 24 sata nakon uspješno liječenog AIMU-a (mRs 0 ili 1 ) nije preporučljivo jer može značajno smanjiti vjerojatnost dugoročno povoljnog ishoda ${ }^{8}$. Osim rane postproceduralne skrbi od iznimne je važnosti i kasniji rehabilitacijski postupak, poglavito za bolesnike kod kojih aktivno liječenje moždanog udara nije dovelo do potpunog oporavka (mRs $\geq 1)^{8}$. Iz svega do sad navedenog može se zaključiti da liječenje moždanog udara u visoko specijaliziranim centrima zahtijeva velik broj educiranog osoblja koje uključuje specijaliste radiologije, neurologije, anesteziologije i fizikalne medicine, radiološke tehnologe, medicinske tehničare i fizioterapeute koji su usko specijalizirani u području neurointervencijske medicine. Važan čimbenik u liječenju i skrbi za bolesnika jesu djelatnici i pomoćno osoblje izvanbolničkog i bolničkog Zavoda za hitnu medicinu koji moraju biti educirani o važnosti brzog prepoznavanja simptoma i transporta bolesnika s AIMU-om u specijalizirani centar, kao i sa specifičnostima njihovog periproceduralnog i postproceduralnog liječenja.

\section{ZAKLJUČAK}

Liječenje AIMU-a značajno je napredovalo u zadnjem desetljeću, ponajprije zahvaljujući napretku i uvođenju mehaničke trombektomije u standardan protokol liječenja. Brza neurološka procjena deficita kod bolesnika s AIMU-om temeljem NIHSS bodovne ljestvice od velike je važnosti u liječenju, ali i u daljnjem praćenju navedenih bolesnika. MT je dokazano povoljna i poželjna metoda liječenja kada govorimo o okluziji velikih krvnih žila u mozgu, a IVT je jedina dokazano povoljna metoda liječenja okluzija krvnih žila manjeg promjera. Ukoliko nema kontraindikacija, IVT je potrebno primijeniti što je ranije moguće, odmah nakon dokazane okluzije krvne žile na CTA. Razvojem novih radioloških dijagnostičkih uređaja i standardiziranih protokola snimanja, danas je moguća objektivnija procjena ranih znakova ishemije moždanog parenhima što je izravno utjecalo na liječenje AIMU-a. Ovisno o opsegu ranih ishemijskih promjena na mozgu, aktivno liječenje mehaničkom trombekto- mijom provodi se do 24 sata od nastupa simptoma, što potvrđuju i multicentrične randomizirane studije DAWN i DEFUSE 3.

U ovom su radu opisane četiri najčešće korištene tehnike MT-a, a izbor tehnike u velikoj mjeri ovisi o iskustvu i preferencijama operatera, iako studije u većoj mjeri idu u prilog tehnikama koje koriste samošireći uvlačivi stent. Razvojem novih materijala i usavršavanjem specijaliziranog osoblja te osnivanjem novih specijaliziranih centara za liječenje AIMU-a svakodnevno se proširuju i in-

U Republici Hrvatskoj je u studenom 2020. u sve kliničke bolničke centre uspješno implementiran MT kao dio standardnog protokola liječenja AIMU-a, čime je ostvaren višegodišnji nacionalni plan te je uspostavljena cjelovita mreža visokospecijaliziranih centara za liječenje AIMU-a.

dikacije za liječenje mehaničkom trombektomijom. Posljedično, sve češće susrećemo studije koje potvrđuju povoljne ishode liječenja MT-om na krvnim žilama manjeg promjera, odnosno distalnije od M1 segmenta ACM, kao i na proksimalnim odsječcima arterija prednje i stražnje moždane cirkulacije.

Što se tiče anesteziološke potpore i liječenja, sedacija je dokazano poželjna metoda anesteziološke potpore tijekom zahvata mehaničke trombektomije, dok opću anesteziju treba primijeniti u slučajevima ugroženosti dišnog puta i/ili izrazitog nemira bolesnika.

U Republici Hrvatskoj je u studenom 2020. g. u sve kliničke bolničke centre uspješno implementiran MT kao dio standardnog protokola liječenja AIMU-a, čime je ostvaren višegodišnji nacionalni plan te je uspostavljena cjelovita mreža visokospecijaliziranih centara za liječenje AIMU-a. Na taj je način svim osobama koje borave u Republici Hrvatskoj postalo dostupno najsuvremenije liječenje moždanog udara, sukladno recentnim smjernicama i preporukama relevantnih stručnih društava. Zaključno, možemo reći da je uloga neurointervencijskog tima postala neizostavna u lancu liječenja bolesnika s AIMU-om, kao i da je realno očekivati daljnji napredak MT-a u liječenju AIMU-a. 
Izjava o sukobu interesa: Autori izjavljuju kako ne postoji sukob interesa.

\section{LITERATURA}

1. Baum S, Pentecost MJ. Abrams' angiography: interventional radiology. $2^{\text {nd }}$ Edition. Philadelphia: Lippincott Wiliams \& Wilkins, 2006;837-63.

2. Aguiar de Sousa D, Von Martial R, Abilleira S, Gattringer $T$, Kobayashi A, Gallofré $M$ et al. Access to and delivery of acute ischaemic stroke treatments: A survey of national scientific societies and stroke experts in 44 European countries. Eur Stroke J 2019;4:13-28.

3. Brogueira Rodrigues F, Briosa Neves J, Caldeira D, Ferro $\mathrm{JM}$, Ferreira JJ, Costa J. Endovascular treatment versus medical care alone for ischaemic stroke: systematic review and meta-analysis. BMJ 2016;353:1754.

4. van der Zijden T, Mondelaers A, Yperzeele L, Voormolen M, Parizel PM. Current concepts in imaging and endovascular treatment of acute ischemic stroke: implications for the clinician. Insights Imaging 2019;10:64.

5. Emberson J, Lees KR, Lyden P, Blackwell L, Albers G, Bluhmki $E$ et al. Effect of treatment delay, age, and stroke severity on the effects of intravenous thrombolysis with alteplase for acute ischaemic stroke: a metaanalysis of individual patient data from randomised trials. Lancet 2014;384:1929-35.

6. Državni zavod za statistiku [Internet]. Zagreb: Popis stanovništva 2011. [cited 2020 Dec 9]. Dostupno na: https://www.dzs.hr/Hrv/censuses/census2011/censuslogo.htm.

7. Kampić K, Bonifačić D. Važnost ljestvica za zbrinjavanje moždanog udara. Med Flum 2018;54:366-72.

8. Powers WJ, Rabinstein AA, Ackerson T, Adeoye OM, Bambakidis NC, Becker K et al. Guidelines for the Early Management of Patients With Acute Ischemic Stroke: 2019 Update to the 2018 Guidelines for the Early Managment of Acute Ischemic Stroke: A Guideline for Healthcare Professionals From the American Heart Association/American Stroke Association. Stroke 2019;50:344-418.

9. Haussen DC, Bouslama M, Grossberg JA, Anderson A, Belagage $S$, Frankel $M$ et al. Too good to intervene? Thrombectomy for large vessel occlusion strokes with minimal symptoms: an intention-to-treat analysis. J Neurointerv Surg 2017;9:917-921.

10. Goldhoorn RB, Verhagen M, Dippel DWJ, van der Lugt A, Lingsma HF, Roos YBWEM et al. Safety and Outcome of Endovascular Treatment in Prestroke-Dependent $\mathrm{Pa}$ tients. Stroke 2018;49:2406-14.

11. Schonewille WJ, Wijman CA, Michel P, Rueckert CM, Weimar C, Mattle HP et al. Treatment and outcomes of acute basilar artery occlusion in the Basilar Artery International Cooperation Study (BASICS): a prospective registry study. Lancet Neurol 2009;8:724-30.
12. Sims JR, Rordorf G, Smith EE, Koroshetz WJ, Lev $M H$, Buonanno $\mathrm{F}$ et al. Arterial occlusion revealed by $\mathrm{CT}$ angiography predicts NIH stroke score and acute outcomes after IV tPA treatment. AJNR Am J Neuroradiol 2005;26:246-251.

13. Goyal M, Menon BK, Coutts SB, Hill MD, Demchuk AM. Effect of baseline CT scan appearance and time to recanalization on clinical outcomes in endovascular thrombectomy of acute ischemic strokes. Stroke 2011;42:93-7.

14. Allen LM, Hasso AN, Handwerker J, Farid H. Sequencespecific MR Imaging findings that are useful in dating ischemic stroke. Radiographics 2012;32:1285-97.

15. Nogueira RG, Jadhav AP, Haussen DC, Bonafe A, Budzik RF, Bhuva $P$ et al. Thrombectomy 6 to 24 hours after stroke with a mismatch between deficit and infarct. $\mathrm{N}$ Engl J Med 2018;378:11-21.

16. Albers GW, Marks MP, Kemp S, Christensen S, Tsai JP, Ortega-Gutierrez $S$, et al. Thrombectomy for stroke at 6 to 16 hours with selection by perfusion imaging. N Engl J Med 2018;378:708-18.

17. Brinjikji W, Pasternak J, Murad MH, Cloft HJ, Welch TL, Kallmes DF et al. Anesthesia-related outcomes for endovascular stroke revascularization: A systematic review and meta-analysis. Stroke 2017;48:2784-91.

18. Löwhagen Hendén $P$, Rentzos $A$, Karlsson JE, Rosengren L, Leiram B, Sundeman $\mathrm{H}$ et al. General anesthesia versus conscious sedation for endovascular treatment of acute ischemic stroke: The AnStroke trial (Anesthesia During Stroke). Stroke 2017;48:1601-7.

19. Schönenberger S, Uhlmann L, Hacke W, Schieber S, Mundiyanapurath S, Purrucker JC et al. Effect of conscious sedation vs general anesthesia on early neurological improvement among patients with ischemic stroke undergoing endovascular thrombectomy: A randomized clinical trial. JAMA 2016;316:1986-96.

20. Parthasarathy R, Gupta V. Mechanical thrombectomy: Answering unanswered. Ann Indian Acad Neurol 2020; 23:13-9.

21. Hesse AC, Behme D, Kemmling A, Zapf A, Große Hokamp $\mathrm{N}$, Frischmuth I et al. Comparing different thrombectomy techniques in five large-volume centers: A 'real world' observational study. J Neurointerv Surg 2018;10:525-9.

22. Liebeskind DS, Bracard $S$, Guillemin F, Jahan R, Jovin TG, Majoie CB et al. eTICl reperfusion: defining success in endovascular stroke therapy. J Neurolnterv Surg 2019; 11:433-8.

23. Jovin TG, Chamorro A, Cobo E, de Miquel MA, Molina CA, Rovira A et al. Thrombectomy within 8 hours after symptom onset in ischemic stroke. $N$ Engl J Med 2015; 372:2296-306

24. Wu X, Khunte M, Ghandi D, Matouk C, Hughes DR, Sanelli $P$ et al. Implications of achieving TICl $2 b$ vs TICl 3 reperfusion in patients with ischemic stroke: a cost-effectiveness analysis. J Neurointerv Surg 2020;12:1161-65. 